\title{
A PERSISTÊNCIA DO CARISMA
}

\author{
TEIXEIRA, Rosana da Câmara \\ Krig-ha, bandolo! Cuidado, aí vem Raul Seixas. \\ Rio de Janeiro: 7Letras/FAPERJ, 2008.
}

POR

Marco Antonio Perruso ${ }^{1}$

riundo de Tese de Doutorado em Antropologia defendida no Programa de
Pós-Graduação em Sociologia e Antropologia do IFCS/UFRJ em 2004, o
livro de Rosana da Câmara Teixeira deve ser considerado um dos principais
trabalhos e análises a respeito de Raul Seixas e do mito em torno dele, persistente
após sua morte, que em 2009 completou 20 anos. Como grande ídolo musical e
ícone cultural brasileiro dos anos 1970/80, muitos são os trabalhos sobre os círculos
artísticos dos quais Raul Seixas fazia parte, vários deles citados pela autoraª
Rosana da Câmara Teixeira indaga a respeito de como certos indivíduos
tornam-se ídolos, investigando que contextos sociais, culturais e políticos estão
envolvidos nesse processo. A relação entre fã/admirador/seguidor, por um lado,
e ídolo/referência, por outro, é algo recorrente na vida cultural e política das
sociedades de várias épocas, ocorrendo também na contemporaneidade. No caso
de Raul Seixas, seu carisma subsistiu à sua morte, não se rotinizou, por vezes

\footnotetext{
${ }^{1}$ Professor Adjunto de Ciências Sociais da Universidade Federal Rural do Rio de Janeiro (DLCS/ ICHS/UFRuralRJ) e Doutor em Sociologia pelo Programa de Pós-Graduação em Sociologia e Antropologia (IFCS/UFRJ). End. eletrônico: trogao@bol.com.br

${ }^{2}$ A título de exemplo, ver Buarque (1997) e Gomes (2000).
} 
se agigantou, tornando-se um fenômeno invulgar que a autora percebe com acuidade.

Teixeira lança mão de uma diversidade de metodologias e recursos para 0 desenvolvimento de sua pesquisa: recorre a documentos dos órgãos de censura da ditadura militar brasileira, leva em consideração recortes de jornais e revistas dos anos 1970/80, entrevista vários fãs e seguidores, participa de comunidades virtuais ligadas a Raul Seixas na internet - inclusive intervindo nos respectivos debates, posicionando- se e se envolvendo em algumas polêmicas protagonizadas por seus membros, o que configura uma observação participante típica. Além disso, utiliza biografias relativas a destacadas figuras do campo artístico, bem como vasta bibliografia a respeito da música e da cultura no período.

Opta a autora por levar em conta a trajetória de Raul Seixas apenas a partir de seu lançamento enquanto artista-solo, descartando sua trajetória anterior de compositor e produtor, além de cantor que participava de bandas ou projetos. Argumenta neste sentido apontando que sua figura enquanto artista-solo the garantiria uma espécie de aceitação social prévia, o que é inegável. Por outro lado, a presença anterior de Raul Seixas no mundo da música e nas engrenagens da chamada indústria cultural de alguma maneira deve se relacionar à sua aceitação social conquistada posteriormente.

A partir das reflexões de Norbert Elias, Teixeira indaga como obras de certos artistas passam de modo bem-sucedido por processos seletivos de diversas gerações de apreciadores culturais. Carisma, autenticidade e outras noções são operadas conceitualmente para explicar tais situações, sendo úteis se pensadas como características atribuídas ao artista e sua obra pelo apreciador, não como propriedades intrínsecas à obra ou ao seu autor. Raul Seixas seria autêntico no contexto da indústria cultural e/ou seria carismático se comparado a outros artistas. Max Weber e Walter Benjamin, entre outros teóricos, fazem- se presentes nas reflexões da autora. A continuidade do culto a Raul Seixas, mesmo muito após sua morte, significaria que sua autenticidade e excepcionalidade continuam a ser reconhecidas - e assim interpretadas - por diversas gerações de apreciadores culturais.

Teixeira opta por expor diversas possibilidades de interpretação e conceituação a partir das quais poderia se entender o fenômeno da figura de Raul Seixas e do movimento que se processou em torno de si especialmente a partir de sua morte: personagem liminar (Turner), herói dionisíaco, renunciante 
(Dumont), rebelde, outsider, romântico, bufão (Bakhtin), especialmente no capítulo 4: "Essa Metamorfose Ambulante': os muitos personagens de um nome". Mas, privilegia a exposição panorâmica de tais possibilidades analíticas sem hierarquizá-las ou selecionar com maior destaque alguma dentre elas.

Ressalta Teixeira que a morte de Raul Seixas e a comoção que envolveu seu funeral são marcos para o desencadeamento de uma idolatria poderosa. Sua trajetória de músico, cantor e compositor sempre envolvia outras dimensões, além do tradicional prisma comercial implicado pela indústria da música como parte da indústria cultural: especialmente a dimensão política e a dimensão mística/ esotérica/filosófica. Críticas ao modo de vida moderno e às instituições (Igreja, Exército...) eram muito comuns em sua obra, e remetiam à proposta de uma sociedade alternativa, bem como a elementos de resistência à ditadura militar então vigente no Brasil.

Ao mesmo tempo, a autora indica como Raul Seixas era criticado por seu tino comercial, pela ausência de afirmação política nos cânones da esquerda marxista ortodoxa $a^{3}$ ainda tão forte no período, por ser um roqueiro - sendo assim, pouco ligado a um primado nacionalista da música brasileira (ainda que suas músicas incorporassem sons nordestinos, afro-brasileiros, etc.). A autora se refere aqui à assim alcunhada "patrulha ideológica" promovida por certos setores intelectuais da esquerda brasileira, como presente neste contexto e por vezes se voltando contra o próprio Raul Seixas, embora, creio, Teixeira não dimensione com mais cuidado a ironia política e estética constante da "patrulha" exercida, por exemplo, pelo cartunista Henfil no Pasquim. Questão polêmica que deve ser objeto de estudos e debates mais aprofundados.

Voltando às ricas descrições e análises da autora: o sucesso popular de Raul Seixas era enorme. Seu público, diversificado, ao contrário das platéias intelectualizadas de muitos artistas da Tropicália e da MPB, contemporâneos seus, como Caetano Veloso e Chico Buarque. Raul Seixas, contudo, tratava de temas sofisticados de forma simples. Mas a ambigüidade estava, também, presente nas letras de suas canções. Sua inserção no movimento mais geral e mundial, da Contracultura é nítida: contestação radical à sociedade ocidental, experimentação de drogas, etc, estavam presentes em sua obra e em suas atitudes. Por isso também os setores conservadores e de direita o odiavam.

${ }^{3}$ Diferente de Teixeira, uso aqui a noção de marxismo ortodoxo encontrada em Willians (1979). 
Prosseguindo em sua densa pesquisa sobre o culto a Raul Seixas, Teixeira nota que alguns fãs seus mais radicais largavam tudo na vida para se dedicar integralmente a seguir o ídolo. Outros mudavam radical ou parcialmente aspectos de sua vida em função de certas idéias e ideais propagados por Raul Seixas ou buscando um auto-conhecimento autônomo inspirado em sua trajetória. Passeatas são feitas em sua homenagem ou relacionando-o a questões políticas, sociais, comportamentais. Como diz um fã: "Vocês já viram um outro cantor exercer essa 'influência' sobre alguém?" (TEIXEIRA, 2008, p. 134). Neste sentido, poucos artistas foram tão impactantes longevamente no cenário cultural e intelectual brasileiro. Talvez possamos lembrar de Tim Maia, Renato Russo e Racionais MCs, numa certa progressão histórica, mas dificilmente o fenômeno Raul Seixas é igualado em sua amplitude.

Voltando à autora, ela propõe serem os fãs de Raul Seixas identificados mais amplamente como uma vasta e frouxa coletividade, articulada a partir da devoção ao ídolo e da fidelidade às suas idéias, por vezes as mais diversas: contestatórias, libertárias, anarquistas, individualistas, etc. Seriam múltiplas as possibilidades de compreender e se apropriar da obra de Raul Seixas - uma das conclusões mais convincentes a que Teixeira chega.

São essas e outras questões que o trabalho da autora, com muita propriedade, suscita, a respeito da importante figura dos campos cultural, artístico e - por quê não? - intelectual brasileiro que foi Raul Seixas .

\section{REFERÊNCIAS}

BUARQUE, Mônica. Culto-Rock a Raul Seixas: sociedade alternativa entre rebeldia e negociação. Dissertação de Mestrado, Antropologia, UFF, Niterói, 1997.

GOMES, Rodrigo Moreira. Eu quero é botar meu bloco na rua: a biografia de Sergio Sampaio. Niterói: Muiraquitã, 2000.

WILLIANS, Raymond. Marxismo e Literatura. Rio de Janeiro: Zahar, 1979.

${ }^{4}$ Este resenhista mesmo se confessa um fã tardio de Raul Seixas. 